Available online at http://journal.stkip-andi-matappa.ac.id/index.php/histogram/ Histogram : Jurnal Pendidikan Matematika ., 2019, 162 - 171

\title{
PENGARUH PENERAPAN STRATEGI CLASS CONCERN TERHADAP KEMAMPUAN PEMECAHAN MASALAH MATEMATIKA SISWA
}

\author{
Fitriana Rahmawati ${ }^{{ }^{*}}$, Risnawati ${ }^{2}$ \\ ${ }^{1,2}$ STKIP PGRI Bandar Lampung \\ * Corresponding Author. Email: fitriana_rahmawati@stkippgri.ac.id \\ Received: 23 Juli 2019; Revised: 18 Agustus 2019; Accepted: 30 September 2019
}

\begin{abstract}
ABSTRAK
Penelitian ini bertujuan untuk mengetahui pengaruh strategi class concern terhaap kemampuan pemecahan masalah matematika siswa kelas VIII SMP Negeri 1 Natar Lampung Selatan. Penelitian ini menggunakan metode eksperimen, serta analisi data menggunakan rumus statistik. Populai dalam penelitian ini yaitu seluruh kelas VIII SMP Negeri 1 Natar Lampung Selatan, sedangkan sampel diambil 2 kelas VIII 1 sebagai kelas eksperimen dan kelas VIII 2 sebagai kelas kontrol. Pengambilan sampel dengan teknik pengundian. Pengujian hipotesis menggunakan uji-t. Dari hasil pengujian hipotesis menggunakan rumus statistik thitung diperoleh $t=8$,67. Dari tabel distribusi t pada taraf signifikan $5 \%$ diketahui $t_{\text {tabel }}=t_{((1-1 / 2 \alpha))}=2,00$ artinya $t_{\text {hitung }}>t_{\text {tabel }}$ yaitu 8,67 $>2,00$, sehingga bahwa strategi class concern berpengaruh terhadap kemampuan pememcahan masalah matematika kelas VIII SMP Negeri 1 Natar Lampung Selatan.
\end{abstract}

Kata Kunci: Class Concern, Kemampuan Pemecahan Masalah

How to Cite: Rahmawati, F,. \& Risnawati. (2019). Pengaruh Penerapan Strategi Class Concern terhadap Kemampuan Pemecahan Masalah Matematika Siswa. Histogram: Jurnal Pendidikan Matematika, 3(2), 162 - 171, doi: http://dx.doi.org/10.31100/histogram.v3i2.425 Permalink/DOI: http://dx.doi.org/10.31100/histogram.v3i2.425

\section{PENDAHULUAN}

Pentingnya kemampuan pemecahan masalah dimiliki bagi seluruh siswa mulai dari tingkat SMP terlihat salah satunya pada pembelajaran matematika. Dalam pembelajaran ini, pemecahan masalah menjadi tujuan dalam pembelajaran baik pada Kurikulum Tingkat Satuan Pendidikan (KTSP) hingga Kurikulum 2013. Pemecahan masalah matematika sebagai suatu bekal dalam penyediaan potensi sumber daya yang handal yang memiliki pemikiran kritis, sistematis, logis, kreatif, rasional, dan cermat. Pentingnya kemampuan ini juga dikemukakan Branca dalam (Nurman, 2008) yaitu bahwa: (a) pemecahan masalah merupakan tujuan umum pengajaran matematika; (b) pemecahan masalah merupakan proses dalam pembelajaran; dan (c) kemampuan pemecahan masalah merupakan dasar This is open access article under the CC-BY-SA-license. 


\section{Histogram: Jurnal Pendidikan Matematika, 3 (2), 2019 - 163 Fitriana Rahmawati, Risnawati}

dalam belajar matematika. Dengan demikian sudah sewajarnya jika pemecahan masalah menjadi perhatian besar dalam pembelajaran matematika.

Dalam pembelajaran matematika yang ada, ternyata belum sepenuhnya mendukung pentingnya kemampuan tersebut. Kemampuan siswa dalam hal memecahkan masalah masih jauh dari harapan. Terlihat dari nilai sebagian siswa kelas VIII SMP Negeri 1 Natar Lampung Selatan pada mata pelajaran ini masih belum mampu memenuhi standar yang ada.

(Daryanto, 2010), belajar merupakan proses seseorang untuk memperoleh perubahan tingkah laku yang baru bagi dirinya, sebagai hasil pengalamannya dari interaksi dengan lingkungannya. (Sutikno, M., 2004), mengartikan belajar adalah hasil dari suatu usaha dan pengalamannya sendiri dalam interaksi dengan lingkungannya sehingga diperoleh suatu perubahan tingkah laku yang baru.

(Sudjana, 2000) menyatakan bahwa pembelajaran merupakan usaha yang dilakukan dengan sengaja oleh pendidik sehingga dapat menyebabkan peserta didik melakukan kegiatan belajar. (Syafaruddin \& Nasution, 2005) mendefinisikan pembelajaran merupakan aktifitas yang mengatur lingkungan sekitar dengan peserta didik sehingga terjadi proses pembelajaran.

Dalam pemberian materi matematika di kelas VIII, terlihat proses pembelajaran yang bersifat satu arah yang kurang memberikan kesempatan kepada siswa untuk terlibat aktif dalam kegiatan pembelajaran, siswa juga kurang diarahkan untuk berfikir kritis dalam setiap soal matematika yang dihadirkan. Akibatnya siswa terlihat jenuh, cepat bosan dalam pembelajaran yang diberikan, pasif dan kurangnya motivasi belajar matematika sehingga menyebabkan kurangnya kompetensi siswa dalam pembelajaran matematika yang terlihat dari kesulitan siswa jika diberikan soal-soal matematika baik soal prosedural rutin ataupun non rutin yang dihadirkan dalam pembelajaran. situasi pembelajaran yang demikian, dapat mempengaruhi rendahnya hasil dan kemampuan siswa dalam memecahkan masalah matematika.

Joice \& Weil dalam (Isjoni, 2013) mengartikan model pembelajaran yaitu suatu pola yang sudah direncanakan sedemikian rupa sehingga dapat digunakan untuk menyusun kurikulum, mengatur materi pelajaran, dan memberi petunjuk kepada pengajar di kelasnya. Menurut (Hanafiah, N. \& Suhana, 2009), model pembelajaran merupakan salah satu pendekatan untuk mensiasati perubahan tingkah laku peserta didik secara keseluruhan.

Keadaan di atas, tentunya memerlukan penanganan dalam pembelajaran matematika mengingat pentingnya kemampuan pemecahan masalah matematika. Dengan 


\section{Histogram: Jurnal Pendidikan Matematika, 3 (2), 2019 - 164 Fitriana Rahmawati, Risnawati}

analisis permasalahan yang ada, salah satu solusi yang dapat diterapkan melalui model pembelajaran yang lebih dekat dengan siswa serta memberikan kesempatan latihan pemecahan masalah matematika secara mandiri bagi siswa. Salah satu strategi pembelajaran tersebut diantaranya class concern.

Strategi Class Concern merupakan sebuah cara untuk mendapatkan partisipasi siswa . dengan strategi ini siswa dapat lebih aktif dalam pambelajaran yaitu memberikan kesempatan siswa untuk bertanya dan bekerjasama dalam kelompok supaya dapat menyelesaikan tugas yang diberikan. Strategi Class Concern (perhatian terhadap aktivitas kelas) yaitu suatu cara dari belajar aktif dan penilaian secara cepat. (Silberman, 2009) mengungkapkan: Strategi Class Concern yaitu bagian dari strategi penilaian secara cepat, kegiatan ini mengharuskan kepedulian agar diungkapkan dan dibicarakan secara terbuka namun dengan cara yang baik. Belajar tidak terlepas dari kegiatan.

Sebagaimana yang diungkapkan oleh (Sardiman, 2014), "Setiap orang yang belajar harus berperan, tanpa adanya peran maka proses belajar tidak akan terjadi”. Sedangkan Menurut Polya dalam (Gunantara, G., Suarjana, I. M., \& Riastini, 2014), kemampuan pemecahan masalah adalah "proses yang ditempuh oleh seseorang untuk menyelesaikan masalah yang dihadapinya sampai masalah itu tidak lagi menjadi masalah baginya", sedangkan menurut Gagne (Gunantara, G., Suarjana, I. M., \& Riastini, 2014), kemampuan pemecahan masalah merupakan "prosedur atau strategi yang mengharuskan seseorang agar dapat meningkatkkan kemandirian dalam berpikir".

Tujuan dari strategi class concern yaitu membuat siswa lebih berperan dalam proses pembelajaran sehingga siswa mampu meningkatkan kemampuan pemecahan masalah matematikanya dengan cara memberi kesempatan siswa bertanya dan aktif dalam proses pembelajaran.

\section{METODE PENELITIAN}

Penelitian ini dilksanakan di SMP Negeri 1 Natar Lampung Selatan dan menggunakan metode eksperimen yaitu dengan memberikan pembelajaran menggunakan strategi class concern, kemudian dianalisis bagaimana pengaruhnya terhadap kemampuan pemecahan masalah matematika siswa. Dalam penelitian ini penulis akan menggunakan dua kelas yaitu satu kelas sebagai kelas eksperimen yang menerapkan model pembelajaran class concren dan satu kelas sebagai kelas kontrol yang menerapkan model pembelajaran konvensional.

Pengukuran data dalam penelitian ini dalam bentuk tes. tes yang digunakan adalah tes uraian. kemampuan pemecahan masalah matematika sesuai materi ajar dengan jumlah 


\section{Histogram: Jurnal Pendidikan Matematika, 3 (2), 2019 - 165 Fitriana Rahmawati, Risnawati}

soal tertentu. Untuk mempermudah dalam proses pemberian skor hasil pekerjaan siswa maka penulis membuat rubrik penskoran dengan skor tiap butir disesuikan dengan indikator kemampuan pemecahan masalah matematika siswa. Rubrik penskoran kemampuan pemecahan masalah matematika yang akan digunakan mengadaptasi empat aspek kemampuan pemecahan masalah dari (Polya, 1985) seperti yang dinyatakan oleh (Mufarida, 2008) berikut:

Tabel 1. Rubrik Penskoran Kemampuan Pemecahan Masalah Matematika

\begin{tabular}{|c|c|c|}
\hline $\begin{array}{l}\text { Aspek Yang } \\
\text { Dinilai }\end{array}$ & Reaksi Terhadap Soal (Masalah) & Skor \\
\hline \multirow{4}{*}{$\begin{array}{c}\text { Memahami } \\
\text { Masalah }\end{array}$} & $\begin{array}{l}\text { Tidak menuliskan/tidak menyebutkan apa yang } \\
\text { diketahui dan apa yang ditanyakan dari soal. }\end{array}$ & 1 \\
\hline & Hanya menuliskan/menyebutkan apa yang diketahui. & 2 \\
\hline & $\begin{array}{l}\text { Menuliskan/menyebutkan apa yang diketahui dan apa } \\
\text { yang ditanyakan dari soal dengan kurang tepat. }\end{array}$ & 3 \\
\hline & $\begin{array}{l}\text { Menuliskan/menyebutkan apa yang diketahui dan apa } \\
\text { yang ditanyakan dari soal dengan tepat. }\end{array}$ & 4 \\
\hline \multirow{4}{*}{$\begin{array}{l}\text { Merencanakan } \\
\text { Penyelesaian }\end{array}$} & Tidak menyajikan urutan langkah penyelesaian & 1 \\
\hline & $\begin{array}{l}\text { Menyajikan urutan langkah penyelesaian, tetapi urutan- } \\
\text { urutan penyelesaian yang disajikan kurang tepat. }\end{array}$ & 2 \\
\hline & $\begin{array}{l}\text { Menyajikan urutan langkah penyelesaian yang benar, } \\
\text { tetapi mengarah pada jawaban yang salah. }\end{array}$ & 3 \\
\hline & $\begin{array}{l}\text { Menyajikan urutan langkah penyelesaian yang benar } \\
\text { dan mengarah pada jawaban yang benar. }\end{array}$ & 4 \\
\hline \multirow{4}{*}{$\begin{array}{l}\text { Menyelesaikan } \\
\text { Rencana } \\
\text { Penyelesaian }\end{array}$} & Tidak ada penyelesaian sama sekali & 1 \\
\hline & Ada penyelesaian, tetapi prosedur tidak jelas. & 2 \\
\hline & $\begin{array}{l}\text { Menggunakan prosedur tertentu yang benar tetapi } \\
\text { jawaban salah. }\end{array}$ & 3 \\
\hline & $\begin{array}{l}\text { Menggunakan prosedur tertentu yang benar dan hasil } \\
\text { benar. }\end{array}$ & 4 \\
\hline $\begin{array}{c}\text { Memeriksa } \\
\text { Kembali }\end{array}$ & $\begin{array}{l}\text { Tidak melakukan pengecekan terhadap proses dan } \\
\text { jawaban serta tidak memberikan kesimpulan. }\end{array}$ & 1 \\
\hline
\end{tabular}




\section{Histogram: Jurnal Pendidikan Matematika, 3 (2), 2019 - 166 Fitriana Rahmawati, Risnawati}

\begin{tabular}{llc}
\hline $\begin{array}{c}\text { Aspek Yang } \\
\text { Dinilai }\end{array}$ & \multicolumn{1}{c}{ Reaksi Terhadap Soal (Masalah) } & Skor \\
\hline & $\begin{array}{l}\text { Tidak melakukan pengecekan terhadap proses dan } \\
\text { jawaban dan memberikan kesimpulan yang salah. }\end{array}$ & 2 \\
& & 3 \\
\cline { 2 - 2 } & Melakukan pengecekan terhadap proses dan jawaban & \\
& dengan kurang tepat serta memberikan kesimpulan yang \\
& benar. & \\
& & \\
& Melakukan pengecekan terhadap proses dan jawaban & 4 \\
& dengan tepat serta membuat kesimpulan dengan benar. & \\
\hline
\end{tabular}

(Sumber: Mufarida, Tahun: 2008)

Sebelum pengujian hipotesis dilakukan, terlebih dahulu dilakukan uji persyaratan yang meliputi uji normalitas data dan uji homogenitas varians.

\section{HASIL DAN PEMBAHASAN}

\section{A. Hasil Penelitian}

Penelitian eksperimen menggunakan strategi class concern pada kelas VIII SMP Negeri 1 Natar Lampung Selatan, yaitu dengan dua kelas sebagai sampel penelitian. Satu kelas sebagai kelas eksperimen yang dalam pembelajaran menerapkan strategi class concern dan satu kelas sebagai kelas kontrol yang dalam pembelajarannya menerapkan model konvensional. Pada akhir pertemuan untuk kedua kelas diberikan tes akhir berupa tes kemampuan pemecahan masalah matematika pada materi bangun ruang sisi datar. Bentuk tes yang diberikan berupa 5 soal uraian. instrument tes selengkapnya terdapat pada lampiran dengan rubrik penskoran yang digunakan untuk memperoleh nilai siswa pada masing-masing kelas dan mengetahui pengaruh dari perlakuan yang diberikan.

Dari hasil tes akhir yang diberikan pada kedua kelas, diperoleh perbedaan hasil mengenai kemampuan pemecahan masalah matematika siswa baik pada kelas eksperimen maupun pada kelas kontrol. Dari hasil pengambilan sampel didapat kelas eksperimen yaitu kelas VIII 1 yang berjumlah 30 siswa, kelas kontrol yaitu kelas VIII 2 yang berjumlah 30 siswa. Data-data yang diperoleh setelah melalui proses konversi untuk masing-masing nilai, diperoleh nilai-nilai yang berbeda. Adapun gambaran hasil tes akhir pemecahan masalah matematika siswa pada kedua kelas tersebut dapat dilihat pada tabel 2 sebagai berikut. 


\section{Histogram: Jurnal Pendidikan Matematika, 3 (2), 2019 - 167 Fitriana Rahmawati, Risnawati}

Tabel 2. Perbandingan Kemampuan Pemecahan Masalah Matematika Siswa Kelas Eksperimen \& Kelas Kontrol

\begin{tabular}{ccc}
\hline Sebaran Data & Strategi class concern & Model Konvensional \\
\hline Minimal & 56 & 24 \\
\hline Maksimal & 100 & 85 \\
\hline Mean & 87,23 & 59,8 \\
\hline Median & 89,5 & 60 \\
\hline Modus & 100 & 78 \\
\hline Standar Deviasi & 10,66 & 13,67 \\
\hline Jumlah Siswa & 30 & 30
\end{tabular}

(Sumber: Data Primer, Tahun: 2019)

Berdasarkan tabel di atas, dapat dikatakan bahwa kemampuan pemecahan masalah matematika pada kels yang menerapkan strategi class concern serta kelas yang menerapkan model konvensional mempunyai perbedaan kemampuan pemecahan masalah matematika siswa. Dari tabel terlihat juga bahwa kemampuan pemecahan masalah matematika siswa menggunakan strategi class concern memiliki nilai rata-rata atau mean lebih tinggi dibandingkan dengan menggunakan model konvensional.

\section{Pengujian Persyaratan Analisis}

Sebelum pengujian hipotesis dilakukan, terlebih dahulu dilakukan uji persyaratan yang meliputi uji normalitas data dan uji homogenitas varians. Rangkuman uji normalitas dan homogenitas sebagai berikut.

a. Uji Normalitas Data Kelas Eksperimen \& Kelas Kontrol

Berdasarkan hasil perhitungan dengan menggunakan rumus chi kuadrat pada data kelas eksperimen diperoleh $\chi_{\text {hit }}^{2}=4,18$. Untuk taraf signifikan 5\% dengan demikian terlihat $\chi_{\text {hit }}^{2} \leq \chi_{\text {daf }}^{2}$, maka Ho diterima yang berarti sampel kelas eksperimen berdistribusi normal. Kemudian dari hasil perhitungan dengan menggunakan rumus chi kuadrat pada kelas kontrol diperoleh $\chi_{\text {hit }}^{2}=1,8$. Untuk taraf signifikan 5\% dengan demikian terlihat $\chi_{\text {hit }}^{2} \leq \chi_{\text {daf }}^{2}$, maka Ho diterima yang berarti sampel pada kelas kontrol berdistribusi normal.

Berdasarkan perolehan hasil uji normalitas dari kedua kelas di atas, terbukti bahwa sampel kelas ekperimen maupun kontrol berdistribusi normal. kemudian dilanjutkan dengan pengujian varians kedua data. 


\section{Histogram: Jurnal Pendidikan Matematika, 3 (2), 2019 - 168 Fitriana Rahmawati, Risnawati}

b. Uji Homogenitas Varians

Berdasarkan pengujian dua populasi yang telah terbukti berdistribusi normal diperoleh $F_{\text {hit }}=1,65$ Untuk $\alpha=5 \%$ dari tabel didapat: $\mathrm{F}_{\text {daf }}=1,86$

Ternyata $F_{h i t} \leq F_{d a f}$ sehingga hipotesis $H_{o}$ diterima yang berarti kedua data mempunyai varians yang sama (homogen). Berdasarkan perolehan hasil uji homogenitas di atas, terbukti bahwa kedua sampel memiliki varians yang sama.

\section{Pengujian Hipotesis}

Berdasarkan perhitungan diperoleh $\mathrm{s}^{2}=10,66$ dengan $\mathrm{t}_{\mathrm{hit}}=8,67$ dan $\mathrm{t}_{\mathrm{daf}}=2,00$. Dari perhitungan terlihat bahwa $t_{\text {hit }}>t_{d a f}$ maka Ho ditolak, berarti Ha diterima atau dapat dikatakan bahwa rata-rata kemampuan pemecahan masalah matematika siswa dengan menggunakan strategi class concern tidak sama dengan rata-rata kemampuan pemecahan masalah matematika siswa dengan menggunakan model pembelajaran konvensional. Dengan demikian karena $t_{\text {hit }}>t_{\text {daf }}$ maka penerapan strategi class concern berpengaruh terhadap kemampuan pemecahan masalah matematika siswa.

\section{B. Pembahasan}

Berdasarkan hasil penelitian dan analisis data yang terdapat pada lampiran, maka diperoleh gambaran secara umum tentang strategi class concern terhadap kemampuan pemecahan masalah matematika siswa kelas VIII Semester Genap SMP Negeri 1 Natar Lampung Selatan.

Strategi class concern, dimana dalam penelitian ini sebagai variabel bebas merupakan salah satu model pembelajaran berbasis masalah yang membelajarkan siswa terhadap masalah yang ada di sekitar mereka melalui menganalisis contoh gambar-gambar/ foto/ kasus yang memuat masalah yang melatih siswa menganalisis, mengidentifikasi masalah, serta mencari alternatif solusi dari setiap masalah yang dihadapi secara efektif.

Dalam pelaksanaan pembelajaran di kelas eksperimen dengan strategi class concern memberikan siswa kesempatan untuk membelajarkan kepekaan siswa terhadap permasalahan

yang ada di sekitar melalui analisis permasalahan yang ada. Siswa kemudian diarahkan untuk mengidentifikasi masalah, mencari alternatif pemecahan masalah, dan menentukan cara pemecahan masalah yang paling efektif sebagai titik awal pembelajaran.

Dengan terbiasanya siswa untuk menganalisis masalah selanjutnya dapat digunakan untuk memperluas pemahaman konsepnya yang lebih mendalam dan kompleks melalui proses penemuan langsung yang dilakukan oleh siswa. Pengalaman ini yang 


\section{Histogram: Jurnal Pendidikan Matematika, 3 (2), 2019 - 169 Fitriana Rahmawati, Risnawati}

mendorong mereka untuk membangun konsep secara progresif serta mengeksplorasi karakteristik dari suatu konsep dengan mempertimbangkan bagian permasalahan yang dimungkinkan masih terdapat beberapa bagian yang merupakan suatu karakter dari konsep yang telah dipaparkan pada bagian sebelumnya. Dengan demikian jelas bahwa pembelajaran yang ada menjadikan siswa aktif untuk mengemukakan pendapatnya. Tentunya akan tercipta pembelajaran yang berpusat pada siswa.

Keadaan pembelajaran pada kelas VIII 1 sebagai kelas eksperimen yang menggunakan strategi class concern ini memperlihatkan situasi siswa yang aktif bersama kelompoknya untuk menganalisis permasalahan yang disajikan dalam lembar kerja siswa. Selanjutnya hasil analisis ini digunakan kelompok siswa untuk memperluas pemahaman konsepnya yang lebih mendalam sebagai modal memecahkan masalah matematika yang dihadirkan. Siswa juga terlihat memanfaatkan media pembelajaran seperti buku dan lain sebagainya yang dihadirkan agar mampu menguasai konsep bangun ruang sisi datar secara kompleks dengan penemuan mandiri dalam kelompok.

Keadaan siswa pada kelas kontrol justru menunjukan kedaaan yang berlawanan. Pada kelas kontrol siswa terlihat pasif dan susah menerima materi yang diberikan oleh guru. Hasil penelitian pada kelas eksperimen juga mendukung dengan perolehan rata-rata tes kemampuan pemecahan masalah matematika siswa dengan menerapkan strategi class concern lebih tinggi dengan rata-rata kemampuan pemecahan masalah matematika siswa yaitu 87,23 sedangkan siswa yang menerapkan model pembelajaran konvensional lebih rendah dengan rata-rata kemampuan pemecahan masalah matematika siswa yaitu 59,8.

Berdasarkan perhitungan statistik juga didapat $\mathrm{t}_{\text {hit }}=8,67$ dengan melihat kriteria uji dengan taraf 5\% diperoleh $\mathrm{t}_{\text {daf }}=2,00$, dimana dengan kriteria uji $t_{(1-n)}<\mathrm{t}_{\text {hit }}<t_{(1-n)}$ tidak terpenuhi sehingga $\mathrm{H}_{0}$ di tolak, berarti $\mathrm{H}_{\mathrm{a}}$ diterima yang artinya "Rata-rata kemampuan pemecahan masalah matematika siswa yang menggunakan Strategi Class Concern tidak sama dengan rata-rata kemampuan pemecahan masalah matematika siswa yang menggunakan model pembelajaran konvensional pada siswa kelas VIII SMP Negeri 1 Natar Lampung Selatan", atau dapat dikatakan ada pengaruh perlakuan yang diberikan.

Berdasarkan kajian di atas serta hasil analisis data yang penulis uraikan, maka penulis menyimpulkan bahwa "penerapan Strategi Class Concern berpengaruh terhadap kemampuan pemecahan masalah matematika siswa kelas VIII SMP Negeri 1 Natar Lampung Selatan". 


\section{Histogram: Jurnal Pendidikan Matematika, 3 (2), 2019 - 170 Fitriana Rahmawati, Risnawati}

\section{KESIMPULAN DAN SARAN}

\section{A. Kesimpulan}

Perolehan rata-rata kemampuan pemecahan masalah matematika siswa yang menggunakan strategi class concern lebih tinggi dari rata-rata kemampuan pemecahan masalah matematika siswa yang menggunakan pembelajaran konvensional yaitu 87,23 > 59,8. Berdasarkan hasil analisis data yang diperoleh, maka dapat disimpulkan bahwa "Ada pengaruh penerapan strategi class concern terhadap kemampuan pemecahan masalah matematika siswa kelas VIII SMP Negeri 1 Natar Lampung Selatan”.

\section{B. Saran}

Saran yang dapat diberikan untuk perbaikan penelitian yang sama berikutnya, yaitu sebaiknya dalam pembelajaran matematika dapat menggunakan strategi class concern guna mengembangkan serta memaksimalkan kemampuan pemecahan masalah matematika siswa serta memperbaiki kualitas pembelajaran matematika pada tingkat SMP dengan membuat siswa aktif dan dapat berpartisipasi dalam pembelajaran sehingga siswa lebih kreatif dan dapat bekerjasama antar anggota kelompok yang mencirikan strategi class concern sehingga pembelajaran lebih maksimal dan membantu siswa mengkonstruksi penegetahuannya.

\section{DAFTAR PUSTAKA}

Daryanto. (2010). Media Pembelajaran. Yogyakarta: Gaya Media.

Gunantara, G., Suarjana, I. M., \& Riastini, P. N. (2014). Penerapan Model Pembelajaran Problem Based Learning untuk Meningkatkan Kemampuan Pemecahan Masalah Matematika Siswa Kelas V. MIMBAR PGSD Undiksha, 3(1), 1-10.

Hanafiah, N. \& Suhana, C. (2009). Konsep Strategi Pembelajaran. Bandung: Refika Aditama.

Isjoni. (2013). Pembelajaran Kooperatif. Yogyakarta: Pustaka Pelajar.

Mufarida, A. (2008). Kemampuan Siswa dalam Memecahkan Masalah Matematika Berbentuk Soal Terbuka Pada Materi Jajargenjang Di Kelas VII-C SMP Negeri 1 Bangsal Mojokerto. Universitas Negeri Surabaya.

Nurman, T. . (2008). Profil kemampuan Siswa SMP dalam Memecahkan Masalah Matematika Open Ended Ditinjau dari Perbedaan Tingkat Kemampuan Matematika. Universitas Negeri Surabaya.

Polya, G. (1985). How to Solve it 2nd Edition. New Jersey: Princenton University Press.

Sardiman. (2014). Interaksi dan Motivasi Belajar Mengajar. Jakarta: Raja Grafindo Persada.

Silberman, M. (2009). Active Learning “101” Strategi Pembelajaran Aktif. Yogyakarta: Pustaka Insan Mandiri. 
Histogram: Jurnal Pendidikan Matematika, 3 (2), 2019 - 171

Fitriana Rahmawati, Risnawati

Sudjana, N. (2000). Dasar-Dasar Proses Belajar Mengajar. Bandung: PT. Sinar Baru Algesindo.

Sutikno, M., S. (2004). Menuju Pendidikan Bermutu. Mataram: NTB Press.

Syafaruddin \& Nasution, I. (2005). Manajemen Pembelajaran. Jakarta: Quantum Teaching. 